\title{
O POTRZEBIE REINTERPRETACJI (I NIE TYLKO) NIEKTÓRYCH POJĘĆ W ZAKRESIE SAMORZĄDOWYCH ZADAŃ I KOMPETENCJI
}

Od pewnego czasu coraz częściej pojawiają się istotne problemy związane z wykładnią całego szeregu przepisów regulujących różne sfery działań samorządu terytorialnego. Mają one ważkie znacznie zarówno dla jego praktycznej aktywności, jak i dla organów nadzoru i kontroli nad działalnością jednostek samorządu terytorialnego, a także sądownictwa administracyjnego. Budzą poważne wątpliwości doktrynalne, wyrażane m.in. w publikacjach naukowych ${ }^{1}$, choć gwoli ścisłości należy też stwierdzić, że w wielu opracowaniach, zwłaszcza w komentarzach (przede wszystkim do ustawy o gospodarce komunalnej ${ }^{2}$, i to tych opublikowanych w ostatnich latach), o wielu kontrowersjach i niedostatkach aktualnego ustawodawstwa nie wspomina się, w tym m.in. o kwestiach, o których traktuje ten artykuł ${ }^{3}$. Jednym z takich najbardziej kontrowersyjnych zagadnień jest szeroko rozumiana działalność samorządu w sferze gospodarczej - jej dopuszczalność, uwarunkowania oraz ograniczenia. W tekstach normatywnych i wypowiedziach doktryny przewijają się, w szczególności, trzy pojęcia z tego zakresu, bardzo ściśle ze sobą powiązane. Są nimi: „gospodarka komunalna”, „użyteczność publiczna” i „działalność gospodarcza”. Tworza one swoisty „trójkąt terminologiczny”, którego analiza wyłącznie wedle reguł wykładni językowej często prowadzi do konkluzji całkowicie oderwanych od aktualnego zakresu zadań i ich znaczenia dla ustrojowego statusu samorządu terytorialnego.

Próba wyjaśnienia znaczenia tych trzech terminów i wzajemnych relacji między nimi musi zostać poprzedzona krótkim naświetleniem procesu, już historycznego, pojawiania się tych określeń w tekstach aktów normatywnych i dokonywania zmian w ich zakresach znaczeniowych. Obecny kształt ustawodawstwa jest bowiem konsekwencją owego procesu, który, co też ma istotne znaczenie dla uzasadnienia tytułowej potrzeby reinterpretacji niektórych pojęć, zakończył się przed kilkunastoma laty. A aktualna pozycja ustrojowa i znaczenie samorządu terytorialnego dla rozwoju cywilizacyjnego państwa,

${ }_{1}^{1}$ Zob. m.in. M. Stec, M. Mączyński, Zakres i charakter zadań samorzqdu województwa a sfera użyteczności publicznej, „Kontrola Państwowa” 2016, nr 1, s. 122-143 i cytowana tam literatura.

${ }^{2}$ Ustawa o gospodarce komunalnej z 20 grudnia 1996 r., t.jedn.: Dz. U. 2016, poz. 573 (dalej jako: GospKomU).

${ }^{3}$ Zob. zwłaszcza M. Szydło, Ustawa o gospodarce komunalnej. Komentarz, Warszawa 2008; W. Gonet, Ustawa o gospodarce komunalnej. Komentarz, wzory umów i regulaminów, Warszawa 2010; J. J. Zięty, Ustawa o gospodarce komunalnej. Komentarz, Warszawa 2012; C. Banasiński, K. Jaroszyński, Ustawa o gospodarce komunalnej. Komentarz, Warszawa 2017. 
w tym także gospodarczego i społecznego, wymaga postawienia fundamentalnego pytania o aktualność dotychczasowego rozumienia i interpretacji wskazanych wyżej pojęć, a w konsekwencji, jeżeli w drodze wykładni obowiązujacych przepisów okaże się, że nie ma możliwości uzyskania odpowiadającego dzisiejszym potrzebom rozumienia obecnego ujęcia normatywnego, także pytania o konieczność dokonania istotnych zmian niektórych ustawowych unormowań prawnych.

Pierwsze z tych pojęć - „gospodarka komunalna” nie jest znane żadnej $\mathrm{z}$ trzech ustaw samorządowych: o samorządzie gminnym ${ }^{4}$, samorządzie powiatowym $^{5}$ i samorządzie województwa ${ }^{6}$. Występuje natomiast $\mathrm{w}$ tytule ustawy jej poświęconej i w tekście wielu jej artykułów ${ }^{7}$. Tym samym tylko na jej gruncie można formułować zakres znaczeniowy tego pojęcia ${ }^{8}$. Zgodnie z art. 1 ust. 2 GospKomU: „Gospodarka komunalna obejmuje w szczególności zadania o charakterze użyteczności publicznej, których celem jest bieżące i nieprzerwane zaspokajanie zbiorowych potrzeb ludności w drodze świadczenia usług powszechnie dostępnych”, przy czym w ustawie tej określone zostały „zasady i formy gospodarki komunalnej jednostek samorządu terytorialnego, polegajace na wykonywaniu przez te jednostki zadań własnych, w celu zaspokojenia zbiorowych potrzeb wspólnoty samorządowej” (art. 1 ust. 1). Warto zaznaczyć, że tekst ust. 2 jest jego pierwotna wersja, w ust. 1 zaś dokonano w $1998 \mathrm{r}$ zmiany, związanej z wprowadzaną wówczas drugą fazą reformy terytorialnej, polegającej na zastapieniu terminu „gmina” zwrotem „jednostki samorządu terytorialnego". To oznacza, że rozumienie pojęcia „gospodarka komunalna” stworzone przez ustawodawce w $1996 \mathrm{r}$. na potrzeby samorządu gminnego (innego wówczas nie było) zostało automatycznie i, niestety, bezrefleksyjnie przeniesione na wszystkie kategorie samorządu, w tym także wojewódzkiego, co będzie jedna z przyczyn istniejących obecnie kontrowersji (o czym niżej). Jednak przy okazji przeredagowano ten passus w taki sposób, że budzi on istotne problemy interpretacyjne. O ile bowiem w wersji z $1996 \mathrm{r}$. mowa była o „zasadach i formach gospodarki komunalnej, polegającej na wykonywaniu przez gminę zadań własnych [...]”, czyli było jasne, że to gospodarka komunalna polegała na wykonywaniu zadań, o tyle we wprowadzonej w 1998 r. zmianie druga część zdania (,polegające na wykonywaniu”) nie odnosi się do gospodarki komunalnej, ale do jej zasad i form, co jest całkowicie nielogiczne, gdyż zasady i formy na pewno nie polegają na wykonywaniu czegokolwiek. Należy zatem przyjąć, że mimo tej gramatycznej niezręczności, istota tego przepisu nie uległa przekształceniu, a jego nowelizacja miała na celu jedynie dosto-

${ }^{4}$ Ustawa o samorządzie gminnym z 8 marca 1990 r., t.jedn.: Dz. U. 2016, poz. 446 (dalej jako: SamGminU). Termin „gospodarka komunalna” pojawił się w niej w nowelizacji z 1996 r., jednak już w 1999 zastapiony został zwrotem „gospodarka gminna”.

${ }^{5}$ Ustawa o samorządzie powiatowym z 5 czerwca 1998 r., t.jedn.: Dz. U. 2016, poz. 814 (dalej jako: SamPowU).

${ }^{6}$ Ustawa o samorządzie województwa z 5 czerwca 1998 r., t.jedn.: Dz. U. 2016, poz. 486 (dalej jako: SamWojU).

${ }^{7} \mathrm{O}$ miejscu tej ustawy w systemie prawa zob. C. Banasiński, K. Jaroszyński, op. cit., s. 24 i n.

${ }^{8}$ Zwracają na to uwagę C. Banasiński, M. Kulesza, Ustawa o gospodarce komunalnej. Komentarz, Warszawa 2002, s. 13. 
sowanie zakresu zastosowania tej ustawy do nowego ustroju terytorialnego, czyli poddaniu tej ustawie wszystkich jednostek samorządu terytorialnego ${ }^{9}$. $\mathrm{W}$ tym też brzmieniu przepis ten obowiąuje nadal.

Z kolei pojęcie „użyteczność publiczna” występuje we wszystkich ustawach ustrojowych oraz w cytowanej wyżej GospKomU. Już w SamGminU w wersji pierwotnej pojawiło się to określenie w złożeniu „zadania o charakterze użyteczności publicznej”, a istota przepisu, w którym ono się znalazło (art. 9 ust. 2), sprowadzała się do stwierdzenia, że „gmina oraz inna komunalna osoba prawna może prowadzić działalność gospodarczą wykraczająca poza zadania o charakterze użyteczności publicznej, jeżeli wymagają tego potrzeby społeczne". W kolejnych nowelizacjach tej ustawy, najpierw (w 1993 r.) całkowicie zakazano takiej działalności, a następnie w $1996 \mathrm{r}$. w uchwalonej wówczas GospKomU odesłano do niej (art. 9 ust. 2), gdy chodzi o możliwość prowadzenia działalności gospodarczej wykraczającej poza zadania o charakterze użyteczności publicznej. Wtedy też wprowadzono do art. 9 dalsze ustępy (3 i 4), w których przesądzono, że - po pierwsze - „formy prowadzenia gospodarki komunalnej, w tym wykonywania przez gminę zadań o charakterze użyteczności publicznej, określa odrębna ustawa" (czyli właśnie GospKomU) i - po drugie - „zadaniami użyteczności publicznej, w rozumieniu ustawy, są zadania własne gminy, określone w art. 7 ust. 1, których celem jest bieżące i nieprzerwane zaspokajanie zbiorowych potrzeb ludności w drodze świadczenia usług powszechnie dostępnych”. I w tym brzmieniu przepisy te obowiązuja w dalszym ciagu.

W SamPowU pojęcie „użyteczności publicznej” pojawia się tylko raz, w art. 6 ust. 2 kategorycznie stwierdzającym, że „powiat nie może prowadzić działalności gospodarczej wykraczającej poza zadania o charakterze użyteczności publicznej”. I taki zakaz obowiązuje od momentu uchwalenia tej ustawy.

Bardziej elastyczne są natomiast przepisy SamWojU, w których pojęcie to występuje w trzech miejscach, a to w art. 11, w ust. 1 i 2 art. 13 oraz w art. 50 ust. 1. W tym pierwszym mowa jest o prowadzeniu przez samorząd województwa polityki rozwoju województwa, na którą składa się m.in. „pozyskiwanie i łączenie środków finansowych: publicznych i prywatnych, w celu realizacji zadań z zakresu użyteczności publicznej” (ust. 2 pkt 3). Natomiast w myśl ust. 1 art. 13 „w sferze użyteczności publicznej województwo może tworzyć spółki z ograniczoną odpowiedzialnościa, spółki akcyjne lub spółdzielnie, a także może przystępować do takich spółek lub spółdzielni”, a w kolejnym ustępie ustawodawca stwierdza, że „poza sferą użyteczności publicznej województwo może tworzyć spółki z ograniczoną odpowiedzialnością i spółki akcyjne oraz przystępować do nich, jeżeli działalność spółek polega na wykonywaniu czynności promocyjnych, edukacyjnych, wydawniczych oraz na wykonywaniu działalności w zakresie telekomunikacji służących rozwojowi województwa”. Z kolei w art. 50 ust. 1 mówi się, że „przekazanie województwu mienia Skarbu Państwa [...], służącego wykonywaniu zadań gospodarczych przekraczających zakres użyteczności publicznej, może nastapić na wniosek zarządu województwa, jeżeli mienie to służyć ma realizacji strategii rozwoju województwa i re-

\footnotetext{
9 Potwierdzają to wszyscy autorzy komentarzy cytowanych w przyp. 3.
} 
gionalnych programów operacyjnych [...]". I w takim, w zasadzie pierwotnym, brzmieniu ${ }^{10}$ przepisy te obowiązuja do chwili obecnej.

Dla pełności obrazu, choć bez znaczenia dla dalszych wywodów, należy skonstatować występowanie tego określenia w złożeniu występującym we wszystkich ustawach ustrojowych, w którym na początku występuje wyraz „obiekt” lub „urządzenie”, co daje określenie „obiekty i urządzenia użyteczności publicznej”. Jest o nich mowa tam, gdzie określa się wyłączne kompetencje organu kolegialnego, polegajacce m.in. na stanowieniu prawa miejscowego regulujacego w szczególności zasady i tryb korzystania z obiektów i urządzeń użyteczności publicznej (art. 40 ust. 2 pkt 4 SamGminU, art. 40 ust. 2 pkt 4 SamPowU, art. 18 pkt 1 lit. c SamWojU). Ponadto w art. 7 ust. 1 pkt 15 SamGminU stwierdza się, że „w szczególności zadania własne obejmują sprawy: [...] utrzymania gminnych obiektów i urządzeń użyteczności publicznej”.

Kilkakrotnie wykorzystane zostało to pojęcie w GospKomU. Po pierwsze - w cytowanym wyżej art. 1 ust. 2 stwierdzającym, że „gospodarka komunalna obejmuje w szczególności zadania o charakterze użyteczności publicznej”. Następnie w art. 4 ust. 1 przewiduje się, że ,jeżeli przepisy szczególne nie stanowia inaczej, organy stanowiace jednostek samorząu terytorialnego postanawiaja o [...] wysokości cen i opłat albo o sposobie ustalania cen i opłat za usługi komunalne o charakterze użyteczności publicznej oraz za korzystanie z obiektów i urządzeń użyteczności publicznej jednostek samorządu terytorialnego". W kolejnym artykule (7) formułuje się ograniczenia w stosowaniu niektórych form organizacyjnoprawnych, pisząc, że „działalność wykraczająca poza zadania o charakterze użyteczności publicznej nie może być prowadzona w formie samorządowego zakładu budżetowego". Wreszcie w art. 10 pojawia się wyrażenie „,fera użyteczności publicznej”, poza którą znacznie ograniczona zostaje możliwość tworzenia przez gminę spółek handlowych i przystępowania do nich przez wskazanie dziedzin, w których mogą one działać (ust. 1-3), natomiast w ust. 4, w odniesieniu do samorządu województwa, nastapiło odesłanie do regulacji w SamWojU.

Ostatnim pojęciem, które mieści się w tej triadzie, jest „działalność gospodarcza”. Termin ten ma charakter uniwersalny, gdyż występuje w Konstytucji, w ustawie tej działalności poświęconej ${ }^{11}$, samorządowych ustawach ustrojowych (art. 9 ust. 2 SamGminU, art. 6 ust. 2 SamPowU, w SamWojU mowa jest nie o działalności gospodarczej, lecz o „zadaniach gospodarczych” - art. 50 ust. $1^{12}$ ) i ogromnej liczbie innych ustaw.

Pierwsza kwestia o charakterze wstępnym sprowadza się do pytania: czy kluczowe dla omawianej problematyki pojęcia maja swoje „zakotwiczenie” w przepisach Konstytucji, czy też pozostają w sferze regulacji ustawowej? Zarówno w rozdziale I, jak i VII Konstytucji nie zostały zawarte unormowania

\footnotetext{
${ }^{10}$ Jedynie w nowelizacji z 2010 r. dokonano dwóch poszerzeń: po pierwsze - gdy chodzi o zakres podmiotowy, który został uzupełniony o spółdzielnie, oraz - po drugie - w zakresie przedmiotowym obejmującym od tego momentu także działalność w sferze telekomunikacji.

${ }^{11}$ Ustawa o swobodzie działalności gospodarczej z 2 lipca 2004 r., t.jedn.: Dz. U. 2016, poz. 1829 (dalej jako: SwoDziałGospU).

${ }_{12}$ Zauważa to L. Kieres, w: System prawa administracyjnego, t. 8b: Publiczne prawo gospodarcze, Warszawa 2013, s. 96.
} 
posługujące się terminami „gospodarka komunalna” i „użyteczność publiczna”, natomiast określenie „działalność gospodarcza” występuje w kontekście kreowania zasady wolności gospodarczej (art. 20) i jej ograniczenia (art. 22). To oznacza, że ustawodawca posiada szeroka, nieograniczoną kontekstem konstytucyjnym, możliwość kształtowania zakresu znaczeniowego tych dwóch pierwszych pojęć, natomiast trzecie jako odnoszace się nie tylko do sfery samorządowej znajduje swe zdefiniowanie przede wszystkim w ustawie obecnie zatytułowanej „o swobodzie gospodarczej”. To tam określone zostały cechy, których spełnienie oznacza prowadzenie działalności gospodarczej, i one też będą wyznaczać treść tego pojęcia w odniesieniu do aktywności gospodarczej samorząu terytorialnego.

Wprowadzając „gospodarkę komunalną” jako centralne pojęcie do ustawy z 1996 r., ustawodawca zamierzał - po pierwsze - wskazać na zasadnicze znaczenie tej sfery aktywności samorządu terytorialnego (dowodzi tego też samo uchwalenie specjalnej ustawy tej problematyce poświęconej), po drugie - zdefiniować to pojęcie i - po trzecie - stworzyć podstawę do zakreślenia granic tej gospodarki ${ }^{13}$. Bez watpienia nie uległy zmianie w ciagu tych ponad 20 lat cel i potrzeba stworzenia pewnych normatywnych reguł odnoszacych się do prowadzenia przez samorząd terytorialny aktywności w sferze gospodarczej. Mimo bowiem ogromnych zmian zachodzacych w zakresie i sposobie realizowania zadań publicznych wynikających zarówno z rozwoju informacyjno-cyfrowego państwa i społeczeństwa, jak i ewolucji roli i postrzegania samorządu, jedno nie uległo zmianie - ponoszenie przez niego odpowiedzialności za stan spraw publicznych na obszarze jego właściwości. Niezbędne jest zatem sformułowanie reguł, wedle których będzie samorząd prowadził działalność w sferze określanej mianem gospodarki komunalnej. Zasadne jest zatem pozostawienie odrębnej regulacji, rangi ustawowej, mającej zastosowanie do wszystkich kategorii jednostek samorządu terytorialnego. I dopóki nie zostanie stworzony jeden akt prawny regulujący całokształt problematyki samorządowej (należałoby go nazwać „kodeksem samorządowym”), w którym materia objęta ta ustawą stanowiłaby jeden z jego dużych fragmentów, nie istnieja przesłanki do uchylenia tej ustawy, czego skutkiem byłoby włączenie regulacji $\mathrm{w}$ tym zakresie do poszczególnych ustaw ustrojowych.

Nie ulega jednak wątpliwości, że pozostałe dwie kwestie wymagają bliższego przyjrzenia się i zaproponowania określonych zmian. Już pierwsze sformułowanie zawarte w art. 1 wskazujące, na czym polega ta gospodarka, wymaga aktualnego komentarza. W szczególności dotyczy to ograniczenia pojęcia tej gospodarki do zadań własnych samorządu jako swoistego granicznego punktu, poza którym działalność samorządu nie ma już charakteru komunalne$\mathrm{go}^{14}$. Celem zaś wykonywania tych zadań jest zaspokajanie zbiorowych potrzeb wspólnoty samorządowej. Wprawdzie zbliżone sformułowanie znalazło się w Konstytucji (art. 166 ust. 1 - „Zadania publiczne służące zaspokajaniu potrzeb wspólnoty samorządowej są wykonywane przez jednostkę samorządu terytorialnego jako zadania własne"), to jednak nie zostało ono połączone

${ }^{13}$ Podobnie C. Banasiński, M. Kulesza, op. cit., s. 14.

${ }^{14}$ Zob. L. Kieres, op. cit., s. 61 i n. 
z pojęciem „gospodarka komunalna”. W ten sposób nadano mu dużo szerszy zasięg znaczeniowy ${ }^{15}$. Zwłaszcza że pomięto przymiotnik „zbiorowy” występujacy w SamGminU od momentu jej uchwalenia (art. 7 ust. 1). Z drugiej jednak strony pojęcie zadań własnych budzi istotne zastrzeżenia, zarówno w literaturze, jak i orzecznictwie, brak bowiem materialnego kryterium, które pozwalałoby na jednoznaczne rozróżnienie zadań samorządu i administracji rządowej ${ }^{16}$ i które uzależniałoby powierzanie samorządowi zadań o jedynie lokalnym charakterze ${ }^{17}$. We wskazanym artykule Konstytucji mowa jest o „potrzebach wspólnoty samorządowej”, czyli także tej niemającej charakteru lokalnego, czyli wojewódzkiej. Co więcej, zadania samorządowe służą realizacji zadań państwa, choć określone zadanie wykonywane jest na obszarze działania danego samorządu, spełniając rolę służebną wobec samorządowej

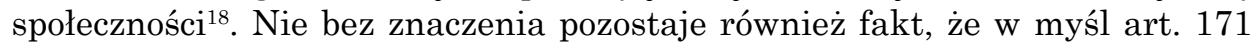
Konstytucji cała działalność samorządu terytorialnego, a zatem wykonywanie zarówno zadań własnych, jak i zleconych, podlega nadzorowi tylko z jednego punktu widzenia, czyli według kryterium legalności ${ }^{19}$. W konkluzji należy zatem przyjaćc, że konstytucyjne określenie zadań własnych obejmuje wszystkie zadania, bez względu na ich naturę ${ }^{20}$, służące zaspokojeniu potrzeb wspólnoty samorządowej, czy to lokalnej (gminnej lub powiatowej), czy regionalnej (wojewódzkiej). Potrzeby te nie muszą też mieć charakteru zbiorowego, jak się jednak podkreśla w literaturze, winny być one potrzebami powszechnymi lub dominującymi, realizującymi wspólne interesy tej społeczności, stając się tym samym potrzebami o charakterze publicznym ${ }^{21}$.

W tym kontekście należy zatem czytać i interpretować przepisy GospKomU. To oznacza, że zadania własne, które zostały uznane w tej ustawie za mieszczące się w pojęciu „gospodarka komunalna”, są jedynie częścią wszystkich zadań własnych jednostek samorządu terytorialnego. To co je odróżnia od pozostałych, to ich charakter wynikający z przynależności do pojęcia „gospodarka komunalna”. O ile przymiotnik „komunalny”, jako synonim terminu „samorządowy”, nie stanowi żadnego elementu ograniczajacego zakres interpretacji pojęcia „zadania własne” (a użyty został w nawiązaniu do pewnej tradycji terminologicznej i faktu użycia tego przymiotnika w SamGminU w wielu miejscach), o tyle istotne znaczenie ma drugi wyraz, czyli ,gospodarka”. Niewątpliwie gospodarka komunalna jest częścią działalności komunalnej, którą wypełniają także inne przejawy aktywności samorządu niemogące być

${ }^{15}$ Zob. A. Skoczylas, W. Piątek, w: M. Safjan, P. Bosek (red.), Konstytucja RP. Komentarz, t. 2, Warszawa 2016, s. 910 i n.

${ }^{16}$ Wyraźnie takie stwierdzenie formułuje TK w swym wyroku z 23 października 1995 r., K 4/95, OTK 1995, nr 2, poz. 31.

17 Tak TK w wyroku z 13 listopada 1996 r., K 17/96, OTK 1996, z. 2, poz. 41.

${ }_{18}$ Zob. wyrok TK z 4 maja 1998 r., K 38/97, OTK ZU 1998, nr 3, poz. 31.

${ }_{19}$ Tak C. Banasiński, M. Kulesza, op. cit., s. 14.

${ }^{20}$ Kategoryzacje tych zadań proponuje Z. Niewiadomski, w: System prawa administracyjnego, t. 6: Podmioty administrujace, Warszawa 2011, s. 140 i n., choć odnosi je tylko do zadań gminy, zob. także J. Zimmermann, Prawo administracyjne, Warszawa 2012, s. 200.

${ }^{21}$ Tak trafnie I. Niżnik-Dobosz, P. Dobosz, w: P. Chmielnicki (red.), Ustawa o samorzadzie gminnym, Warszawa 2013, s. 173; zob. też L. Kieres, op. cit., s. 59 i n. 
zaliczonymi do pojęcia „gospodarka”22, a także jest częścia gospodarki narodowej wyodrębnioną ze względu na kryterium podmiotowe, pozwalające przyporządkować do niej pewną kategorię podmiotów, czyli jednostki samorządu terytorialnego (dalej jako: jst), tak jak można mówić o gospodarce państwowej czy prywatnej. To wydzielenie w pełnym tego słowa znaczeniu stało się możliwe po 1989 r., kiedy przyznano jst status osób prawnych, którym przysługuje najważniejsze prawo podmiotowe, czyli własność określona właśnie mianem własności komunalnej. To na tym substracie majątkowym mogą być kreowane podmioty komunalne, których celem i sensem istnienia jest prowadzenie komunalnej działalności gospodarczej. To w jej ramach realizowane sa te zadania samorządu, o których mowa jest w tej ustawie. Mają one zatem charakter gospodarczy ${ }^{23}$. Znaczenia tego określenia szukać należy w SwoDziałGospU, w której wyraźnie definiuje się ją w art. 2 jako zarobkowa działalność wytwórcza, budowlana, handlowa, usługowa oraz jako poszukiwanie, rozpoznawanie i wydobywanie kopalin ze złóż, a także działalność zawodowa, wykonywana w sposób zorganizowany i ciagły. Od strony przedmiotowej te zadania, które zostały określone w GospKomU, mieszczą się, co do zasady, w tej definicji, a zwłaszcza w pierwszym jej fragmencie. Jak się podkreśla w literaturze: „GospKomU nie przesądziła jednoznacznie o sytuacji samorządu terytorialnego wobec gospodarki czy w gospodarce, [...] a ustawodawstwo nie zdystansowało się całkowicie wobec postulatów przyznania samorządowi terytorialnemu uprawnień do realizacji zadań publicznych także przez wykonywanie działalności gospodarczej”24. Mogą zatem jst prowadzić działalność gospodarczą z zastrzeżeniami wynikającymi z GospoKomU i innych ustaw. Natomiast cechy wskazane w definicji $\mathrm{z}$ art. 2 SwobDziałGospU, jakimi winna się ta działalność odznaczać, muszą być interpretowane zgodnie z fundamentalnymi dla samorządu terytorialnymi zasadami sformułowanymi w Konstytucji i ustawach ustrojowych.

Kwestią nierodząca poważnych wątpliwości jest ciagły, profesjonalny i zorganizowany w odpowiedni sposób proces prowadzenia tej działalności. Samorząd jest instytucja gwarantująca mieszkańcom permanentne świadczenie usług czy dostawę dóbr, a to wymusza skonstruowanie właściwego modelu organizacyjnego dla tej działalności. I właśnie też o tym jest omawiana w tym miejscu ustawa. Przymiotem mogacym rodzić pewne zastrzeżenia, a zatem wymagającym interpretacji, jest zarobkowy charakter tej działalności. Jak wielokrotnie podnoszono w doktrynie, i trudno się z tym nie zgodzić, celem prowadzenia komunalnej działalności gospodarczej przez samorząd, jak i tworzenia odpowiednich podmiotów ją realizujących, nie może być osiagnięcie zysku, lecz zaspokojenie określonych potrzeb mieszkańców, czyli członków samorządowej społeczności. Nie znaczy to jednak, że w prowadzeniu tej działalności jst nie

${ }^{22}$ Zwraca na to uwagę L. Kieres, op. cit., s. 69 i n.

${ }^{23}$ Zob. M. Kulesza, C. Banasiński, op. cit., s. 12, słusznie podkreślajacy materialną (przedmiotowa) stronę tych zadań, co wynika z istoty samorządu jako podmiotu prawa publicznego i prywatnego. Zob. watpliwości L. Kieresa, op. cit., s. 75.

${ }^{24}$ Tak w szczególności L. Kieres, op. cit., s. 71. 
powinny się kierować regułami rachunku ekonomicznego ${ }^{25}$. Wręcz przeciwnie, należy oczekiwać, że samorząd będzie dążył do optymalnego zaspokojenia potrzeb mieszkańców z równoczesnym zachowaniem zasad ekonomicznej efektywności prowadzonej aktywności. To oznacza, że to kryterium musi być interpretowane przy uwzględnieniu charakteru tej działalności i społecznego uzasadnienia jej prowadzenia.

W ust. 1 art. 1 wyraźnie się stwierdza, że „ustawa określa zasady i formy gospodarki komunalnej”, co oznacza uznanie tych dwóch kwestii za najistotniejsza jej część. O ile zagadnienie form organizacyjnoprawnych stanowi przeważający fragment ustawy (3 rozdziały), o tyle zasadom nie poświęcono właściwego im miejsca, dlatego trzeba je także formułować na podstawie wykładni niektórych jej przepisów. Tylko w rozdziale I wskazano, że zadania $\mathrm{z}$ zakresu gospodarki komunalnej mogą być wykonywane na podstawie porozumienia z innymi podmiotami, czyli powierzane zarówno osobom fizycznym i prawnym, jak i jednostkom organizacyjnym nieposiadającym tej cechy (art. 4), a w art. 5 wprowadzono regułę, w myśl której to organy stanowiące jst decyduja o wyborze formy organizacyjnoprawnej dla tej działalności. Jednakże najistotniejsze zagadnienie, które może zostać potraktowane jako mieszczące się w kategorii zasad, to rozróżnienie dwóch zasadniczych sfer prowadzenia działalności gospodarczej i wprowadzenie ograniczeń dla jst co do możliwości działania w nich obu i, w konsekwencji, niepozostawienie swobody samorządowi w wyborze form organizacyjnoprawnych dla tej działalności.

Fundamentalne znaczenie dla określenia linii oddzielającej te dwie sfery posiada określenie „użyteczność publiczna”. Zostało ono wykorzystane już w SamGminU (art. 9 ust. 2-4), a następnie powtórzone w GospKomU (art. 1 ust. 2), gdzie - podobnie jak w SamGminU - mówi się o zadaniach o charakterze użyteczności publicznej. Geneza tego określenia i jego prawne rozumienie zostały już w literaturze szeroko przeanalizowane ${ }^{26} \mathrm{i}$ wnioski, jakie zostały sformułowane, sprowadzają się do dwóch tez. Pierwsza zawiera w sobie jednoznaczną konkluzję o konieczności odejścia od historycznego rozumienia tego zwrotu wywodzacego się jeszcze z ustawy o przedsiębiorstwach państwowych z $1981 \mathrm{r} .{ }^{27}$ To oznacza, że całkowicie anachroniczne i nieprzystające do chwili obecnej jest ograniczanie zakresu tego pojęcia do tylko takich potrzeb społecznych, „które w danych warunkach cywilizacyjno-kulturowych i społeczno-gospodarczych sa potrzebami elementarnymi”"28 lub „potrzebami absolutnymi, odczuwanymi bez względu na sytuację społeczna, w jakiej znajduje się

${ }^{25} \mathrm{Z}$ bogatej literatury na ten temat zob. L. Kieres, op. cit., s. 74 i n.; W. Gonet, op. cit., s. $12 \mathrm{i} \mathrm{n.}$

${ }^{26}$ Wieloaspektową analizę tego pojęcia zob. m.in. L. Kieres, op. cit., s. 72 i n.; W. Gonet, Spótki komunalne, Warszawa 2008, s. 12 i n.; S. Dudzik, Działalność gospodarcza samorzqdu terytorialnego. Problematyka prawna, Kraków 1998, s. 295 i n.; M. Szydło, op. cit., s. 145 i n. Ostatnio najszerzej kwestię tę podjęli M. Stec, M. Mączyński, op. cit., s. 130 i n.

${ }^{27}$ Tak M. Stec, M. Mączyński, op. cit., s. 131 i n. Zob. też Z. Dziembowski, Problemy gospodarki finansowej komunalnych zaktadów użyteczności publicznej, „Samorząd Terytorialny” 1994, nr 5 , s. 52 .

${ }^{28}$ Tak A. Wasilewski, Przedsiębiorstwo użyteczności publicznej $w$ świetle prawa polskiego, „Przegląd Ustawodawstwa Gospodarczego” 1982, nr 1-2, s. 12. 
człowiek. Zaspokojenie tych potrzeb umożliwia człowiekowi dopiero podjęcie jego społecznych funkcji”"29. Potrzeby te obecnie sa znacznie poszerzone i nie moga zostać sprowadzone do poziomu życia i aspiracji społeczeństwa z lat osiemdziesiątych XX w. Niezbędne jest odniesienie do współczesnych oczekiwań członków społeczności samorządowych. A one są wyrażane poprzez ewoluujący zakres zadań samorządu znajdujący swój wyraz w odpowiednim unormowaniu prawnym. Inaczej były one ujęte w SamGminU z 1990 r., a inaczej w kolejnych jej nowelizacjach i uchwalonych osiem lat później dwóch pozostałych ustawach ustrojowych. Dlatego druga teza nakazuje połączyć istotę użyteczności publicznej z przedmiotem i zakresem zadań własnych, jaki jest przewidziany w tych ustawach ${ }^{30}$. Najwyraźniej rysuje się to w odniesieniu do samorzadu regionalnego.

Jeżeli zatem w SamWojU stwierdza się, że do zadań własnych samorządu województwa należy „tworzenie warunków rozwoju gospodarczego, w tym kreowanie rynku pracy” (art. 11 ust. 2 pkt 1) czy ,utrzymanie i rozbudowa infrastruktury społecznej i technicznej o znaczeniu wojewódzkim" (art. 11 ust. 2 pkt 2), to przedsięwzięcia mające na celu realizację tych zadań posiadają przymiot użyteczności publicznej. Przecież dla samorządu województwa nie przewidziano w zasadzie żadnych zadań, które by odpowiadały wskazanym wyżej, pierwotnym kryteriom wyodrębnienia pojęcia „użyteczność publiczna”. Ich realizacja stanowi domenę samorządu lokalnego, a zwłaszcza gminnego, o którym myślano, opracowując i uchwalając GospKomU. Podstawowym zadaniem samorządu województwa jest kreowanie rozwoju cywilizacyjnego, co oznacza konieczność wyposażenia go w odpowiednie instrumenty prawne umożliwiające realizację tego celu ${ }^{31}$. Bardzo istotnymi narzędziami w tym zakresie są różnego typu formy organizacyjnoprawne prowadzenia działalności gospodarczej, w tym zwłaszcza spółki prawa handlowego ${ }^{32}$. A treść art. 13 ust. 2 SamWojU dotycząca dopuszczalnych typów działalności gospodarczej, w których prawnie możliwe jest wykorzystywanie tychże spółek, kompletnie rozmija się z potrzebami dzisiejszych samorządów i nie znajduje jakiegokolwiek racjonalnego uzasadnienia. Tym bardziej że w art. 50 tej ustawy wyraźnie statuuje się prawo do uzyskania przez województwo od Skarbu Państwa mienia służącego wykonywaniu działalności gospodarczej, niemieszczącej się w zakresie użyteczności publicznej, ale jednak polegającej na realizacji strategii rozwoju województwa.

${ }_{29}$ Tak S. Piątek, Przedsiębiorstwo użyteczności publicznej jako instytucja gospodarcza, Warszawa 1986, s. 65 i n.

${ }^{30}$ Zob. L. Kieres, op. cit., s. 59 i n. oraz 68 i n.

${ }^{31}$ Zob. szerzej M. Stec, Ustrój terytorialnej administracji publicznej w Polsce. Rola samorzq$d u$ terytorialnego: gminy, powiatu $i$ województwa oraz administracji rzadowej $w$ nowoczesnym państwie XXI w., w: Ustrój samorzadu terytorialnego w Polsce (Reforma Administracji Publicznej. Materiaty szkoleniowe), Warszawa 1998, z. 2, s. 10 i n. Zob. też J. Lemańska, Adekwatność prawnej regulacji pozycji zarzqdu województwa $w$ odniesieniu do podstawowego zadania samorzqdu województwa - rozwoju regionalnego, w: M. Stec, K. Małysa-Sulińska (red.), Pozycja ustrojowa organów wykonawczych jednostek samorzadu województwa, Warszawa 2014, s. 194 i n.; eadem, Zakres $i$ stopień samodzielności samorzqdu województwa $w$ procesie programowania $i$ realizacji rozwoju regionalnego, w: M. Stec, K. Bandarzewski (red.), Rozwój regionalny-instrumenty realizacji $i$ rola samorzqdu województwa, Warszawa 2015, s. 28 i n.

${ }^{32} \mathrm{O}$ możliwości ich wykorzystywania zob. szerzej M. Stec, M. Mączyński, op. cit., s. 139 i n. 
To są m.in. udziały w spółkach Skarbu Państwa przekazywane samorządowi, który w ten sposób stał się szybko najważniejszym kreatorem, a zarazem partnerem w rozwoju gospodarczym regionu. Widać więc sprzeczność w oznaczeniu dozwolonego zakresu aktywności gospodarczej tego samorządu. Z jednej strony w art. 13 ust. 2 stwierdza się, że jest tylko wąski, enumeratywnie wskazany, zakres wykorzystania konstrukcji spółki poza sferą użyteczności publicznej, a w art. 50 ust. 1 uznaje się, że nie ma przeszkód w przekazywaniu samorządowi przez Skarb Państwa mienia do wykonywania zadań niemajacych charakteru użyteczności publicznej, ale związanych z realizacją strategii rozwoju województwa lub regionalnych programów operacyjnych ${ }^{33}$.

Nie można jednak byłoby twierdzić, że pełną aktualność przedstawia dotychczasowe pojmowanie pojęcia „użyteczność publiczna” w relacji do obu samorządów lokalnych. Choć niewątpliwie są one zobowiąane do zagwarantowania świadczenia usług o charakterze użyteczności publicznej w tym pierwotnym rozumieniu, co znajduje wyraźne potwierdzenie w brzmieniu art. 9 ust. 4 SamGminU, to jednak w chwili obecnej ich zadania są dużo szersze i też obejmuja sferę rozwoju gospodarczego i społecznego odpowiedniej wspólnoty. Traktowanie zadań w tym zakresie jako niemających przymiotu użyteczności publicznej, co oznaczałoby niemożność wykorzystywania m.in. instytucji spółek, byłoby anachroniczne i całkowicie nieracjonalne.

Po sformułowaniu powyższej oceny dotychczasowego kształtu normatywnego omawianego zagadnienia i zrelacjonowawszy poglądy doktryny, należy zaproponować odmienne od dotychczasowego rozumienie tych dwóch zasadniczych pojęć, czyli „gospodarka komunalna” i „użyteczność publiczna”. Jest to zabieg niezbędny, w chwili obecnej bowiem przyjmowanie zastanych i, jak wskazano, całkowicie nieadekwatnych do współczesnych warunków funkcjonowania samorządu i funkcji, jakie odgrywa, znaczeń obu pojęć prowadzić może do bardzo negatywnych, o wymiernych skutkach społecznych, gospodarczych i finansowych, konsekwencji, czego najbardziej dobitnym przykładem była kontrowersje powstałe w kontekście wyników kontroli NIK $^{34}$.

Punktem wyjścia dalszych konkluzji jest stwierdzenie, że samorząd terytorialny wszystkich stopni w celu realizacji swoich istotnych i szeroko zakreślonych ustawowych zadań publicznych musi prowadzić działalność gospodarcza, choć nie oznacza to poddania jej wszystkim regulacjom prawnym zawartym w SwobDziałGospU. Niewątpliwie odznacza się ona wieloma szczególnymi cechami, a także winna być poddana specyficznym ograniczeniom, czego odpowiednim miejscem unormowania jest GospKomU. To właśnie w tej ustawie należy stworzyć pełne uregulowanie tego, co w zostało zawarte w art. 1 obecnej ustawy, a co nie zostało, co wyżej zasygnalizowano, w sposób właściwy wykonane ${ }^{35}$. Zarówno gdy chodzi o kwestie merytoryczne, jak i formalno-

${ }^{33} \mathrm{O}$ tym zastanawiającym dysonansie, wręcz sprzeczności, nie wspominaja, niestety, autorzy publikacji cytowanych w tym artykule, choć w tym kształcie przepis ten obowiązuje od 2006 r., czyli od uchwalenia ustawy o zasadach prowadzenia polityki rozwoju (t.jedn.: Dz. U. 2016, poz. 383).

34 „Realizacja zadań publicznych przez spółki tworzone przez jednostki samorządu terytorialnego" - raport NIK z 9 marca 2016 r. Zob. też M. Stec, M. Mączyński, op. cit., s. 136 i n.

${ }_{35} \mathrm{Na}$ niekompletność rozwiązań prawnych przyjętych w tej ustawie i ich nieuporządkowanie wskazują C. Banasiński, K. Jaroszyński, op. cit., s. 24 i n. 
-legislacyjne związane z lokalizacją określonej regulacji. Nie do zaakceptowania jest bowiem aktualny stan, w którym przepisy w omawianym zakresie w odniesieniu do gminy znajdują się w GospKomU, a dotyczące powiatu i województwa w odpowiednich ustawach ustrojowych. Zamieszanie w tym zakresie, potęgowane koniecznością zamieszczania odpowiednich odesłań, jest całkowicie niezrozumiałe, nie istnieją bowiem żadne merytoryczne przesłanki takiego „ulokowania” przepisów.

Pierwsza kwestia to znalezienie odpowiedniego miejsca w siatce pojęciowej dla określenia „gospodarka komunalna”. Nie jest to pojęcie nieprzydatne, natomiast wymaga, by dookreślić je w kontekście jego ustawowego zdefiniowania. Po pierwsze - niewątpliwe należy uznać, że jest ona częścią gospodarki narodowej. Po drugie - użycie terminu „gospodarka” oznacza, że aktywność mieszcząca się w tym pojęciu jest działalnością gospodarcza, choć oczywiście z zastrzeżeniami, o których wyżej była mowa, a które można ująć jako obowiąywanie szczególnego reżimu prawnego, właściwego do jej podejmowania i wykonywania ${ }^{36}$. Po trzecie - charakterystyczna jest służebna rola odgrywana przez tę działalność polegająca na wspomaganiu realizacji zadań własnych jst mających zawsze charakter publiczny ${ }^{37}$. Po czwarte - działania w jej ramach wykonywane sa najczęśsciej w formach niewładczych ${ }^{38}$. Po piąte - mieści się zasadniczo w sferze dominium, czyli obejmuje działania wykorzystujące mienie komunalne ${ }^{39}$. Po szóste - celem prowadzenia tej działalności nie może być wyłącznie chęć osiagnięcia korzystnego wyniku finansowego w postaci zysku ${ }^{40}$. Tym samym można stwierdzić, że nie cała, lecz tylko część działalności samorządu wyznaczona zakresem jego zadań będzie się wyczerpywała w tym pojęciu.

Drugim zasadniczym zagadnieniem jest, sygnalizowana wyżej, konieczność nowego rozumienia terminu „użyteczność publiczna”. Przyjmując zasadność dalszego wykorzystywania i posługiwania się tym określeniem, jego istoty należy poszukiwać w kontekście zadań przypisanych ustawowo poszczególnym stopniom samorządu terytorialnego jako ich zadania własne. Wszystkie one mają walor szczególnej społecznej doniosłości, gdyż w przeciwnym razie nie miałoby sensu ich wymienianie w tekście normatywnym. Są one tam wyartykułowane, gdyż cechuje je właśnie „użyteczność publiczna”. W tym rozumieniu każde zadanie własne jest użyteczne publicznie, a jedynie od natury tego zadania zależy, czy mieścić się ono będzie w sferze gospodarki komunalnej, czy też nie. Bez wątpienia aktywność sprowadzająca się wyłącznie do wykonywania administracji w postaci wydawania aktów administracyjnych nie będzie mogła być uznana za przejaw komunalnej działalności gospodarczej, podobnie należy potraktować pewne postaci tzw. administracji świadczącej (jak np. działalność w sferze kultury, polegająca m.in. na prowadzeniu szczególnej for-

${ }^{36}$ Tak trafnie L. Kieres, op. cit., s. 8; trudno natomiast podzielić w tym zakresie pogląd M. Szydły, op. cit., s. 38, który wskazuje, że „działalność określana mianem gospodarki komunalnej może mieć zarówno charakter działalności gospodarczej, jak też działalności niegospodarczej, administracyjnej”.

37 Trafnie to akcentuje M. Szydło, op. cit., s. 42.

38 Podkreślają to C. Banasiński, K. Jaroszyński, op. cit., s. 29.

39 Ibidem.

${ }^{40}$ L. Kieres, op. cit., s. 81. 
my organizacyjnoprawnej, jakimi sa instytucje kultury, czy w sferze ochrony zdrowia przez prowadzenie samodzielnych publicznych zakładów opieki zdrowotnej), ale już inne pola aktywności samorządu pozwalają na zakwalifikowanie ich jako sfer mieszczących się w pojęciu gospodarki komunalnej. Co jest oczywiste, gdy chodzi o tę „tradycyjną sferę użyteczności publicznej (o czym piszą wszyscy autorzy), która obejmuje znaczącą większość przejawów administracji świadczącej, ale nie jest już tak klarowne, gdy weźmie się po uwagę tę „najmłodszą” postać działań administracji, polegającą na zarządzaniu, administrowaniu rozwojem ${ }^{41}$. Momentem przełomowym, w którym ta funkcja została nie tylko dostrzeżona, lecz także uznana za wręcz najistotniejszą dla samorządu, była reforma ustroju terytorialnego z 1998 r. kreujacca m.in. samorząd powiatowy i samorząd województwa. To w SamWojU, o czym wyżej była mowa, wyraźnie przesądzono, że sednem misji samorządu wojewódzkiego jest bezpośredni wpływ na rozwój cywilizacyjny regionu przy wykorzystaniu niewładczej metody funkcjonowania administracji w sferze kreowania warunków rozwoju cywilizacyjnego, w tym zwłaszcza stymulowania rozwoju gospodarczego i społecznego. Jest to działalność o charakterze m.in. programowym, planistycznym, organizatorskim, doradczym, promocyjnym, wykorzystujaca przede wszystkim instrumenty negocjacyjne i kontraktowe, takie jak: umowa cywilnoprawna oraz porozumienie i umowa administracyjna. Jak stwierdzono w literaturze: „samorząd województwa posiada funkcję bardziej cywilizacyjną niż policyjno-prawną, bardziej rozwojową niż świadcząca, bardziej ekonomiczną niż administracyjna, stosującą raczej mechanikę działania kontraktualnego i negocjacyjnego niż władcza, zakładającą stosowanie przymusu administracyjnego" ${ }^{2}$.

Tego rodzaju przepisów, kształtujących tę nową postać działań administracji, nie sposób jednak odnaleźć w tekście pozostałych dwóch ustaw ustrojowych. A przecież nie ulega najmniejszych wątpliwości, że zarówno samorząd gminny, jak i powiatowy uznają rozwój gminy i powiatu za swoje kardynalne zadanie publiczne. Co więcej, takie też zadania stawia obu tym samorządom ustawodawca w innych ustawach (co jest przewidziane w odpowiednich przepisach SamGminU - art. 6 ust. 1 i SamPowU - art. 4 ust. 3), w szczególności w ustawie o Narodowym Planie Rozwoju ${ }^{43}$ i ustawie o zasadach prowadzenia polityki rozwoju ${ }^{44}$, gdzie wielokrotnie wszystkie jst uwzględniane są jako podmioty prowadzace politykę rozwoju, obligatoryjni uczestnicy procedur przygotowujacych i realizujacych Narodowy Plan Rozwoju, oraz projektodawcy i wykonawcy składajacych się nań strategii i regionalnych programów operacyjnych. I dziś to zadanie stanowi także dla samorządu lokalnego i jego władz najbardziej ważki, a zarazem spek-

41 Zob. M. Stec, op. cit., s. 10 i n.

${ }^{42}$ Ibidem, s. 10 i n., tak też B. Dolnicki, Samorzad terytorialny, Warszawa 2016, s. 205 i n.; zob. té̇ M. Kulesza, Rozwój regionalny. Zagadnienia instytucjonalne, „Samorząd Terytorialny” 2000, nr 10, s. 3 i n.

${ }^{43}$ Ustawa o Narodowym Planie Rozwoju z 20 kwietnia 2004 r., t.jedn.: Dz. U. 2014, poz. 1448 ze zm.

${ }^{44}$ Ustawa o zasadach prowadzenia polityki rozwoju z 6 grudnia 2006 r., t.jedn.: Dz. U. 2016, poz. $383 \mathrm{ze} \mathrm{zm.}$ 
takularny obszar aktywności, przez pryzmat którego członkowie wspólnoty gminnej czy powiatowej dokonują oceny skuteczności działań swoich organów samorządowych. Czy zatem można odmówić tym działaniom przymiotu „użyteczności publicznej”, gdyż nie zaspokajają one elementarnych potrzeb społecznych w sposób bieżący i nieprzerwany? Czytając literalnie tekst art. 1 ust. 2 GospKomU i dokonując wykładni czysto językowej, można do takiego wniosku dojść. Tak też czyni wielu cytowanych wyżej autorów. Jednak po 20 latach od chwili uchwalenia tej ustawy, wobec wyzwań, jakie postawiła przed samorządem terytorialnym akcesja do Unii Europejskiej, i w kontekście dzisiejszych oczekiwań społeczności lokalnych taka wykładnia nie jest do zaakceptowania. Dlatego należy przyjać, że przepisy te należy interpretować także przy wykorzystaniu wykładni celowościowej (funkcjonalnej), co oznacza istotne poszerzenie spektrum zadań o cesze użyteczności publicznej. Potwierdzenie takiego ujęcia znaleźć można w uchwale TK z 12 marca 1997 r., w której zajął on w tej kwestii jednoznaczne stanowisko, stwierdzając, że „zadania [...] mające charakter »użyteczności publicznej« należy rozumieć możliwie najszerzej i wydaje się, że winny one być utożsamiane z zadaniami publicznymi, których realizacja ciąży na administracji rządowej i samorządowej”" ${ }^{45}$. Czy, przykładowo, znalezienie właściwej, odpowiadającej kwalifikacjom i aspiracjom pracy nie jest wręcz elementarną potrzebą o powszechnym zasięgu, na którą to potrzebę samorząd województwa ma odpowiedzieć przez kreowanie rynku pracy (element polityki rozwoju - art. 11 ust. 2 pkt 1 SamWojU), czy też zapobieganie bezrobociu i aktywizację rynku pracy (zadania samorządu - art. 14 ust. 1 pkt 15 SamWojU)? Przecież najlepszym sposobem na zaspokojenie tej potrzeby jest aktywna działalność samorządu w sferze tworzenia warunków rozwoju gospodarczego, czego istotnymi elementami jest wspieranie przedsiębiorczości (zwłaszcza małych i średnich przedsiębiorców), jak i zachęcanie większych firm do inwestowania w województwie. Czy tego typu aktywność w sposób najbardziej organiczny nie jest użyteczna publicznie? ${ }^{46}$ Każde zatem zadanie publiczne nałożone przez ustawy na samorząd posiada walor użyteczności publicznej, a zwłaszcza takie, które mieści się w tej, wskazanej wyżej, nowej postaci działań administracji obejmującej zarządzanie rozwojem. Równocześnie tego typu aktywność spełnia przesłanki zakwalifikowania jej do sfery gospodarki komunalnej, co uzasadnia postawienie pytania o zakres dopuszczalnych do wykorzystania przez jst form organizacyjnoprawnych właściwych do prowadzenia działalności gospodarczej.

Generalnie rzecz ujmując, realizują tę działalność jednostki organizacyjne utworzone w celu wykonywania tych zadań, „których celem jest zaspokajanie potrzeb powszechnych społeczeństwa o charakterze ogólnym, należacych do zadań publicznych, a których działalność nie jest nastawiona na maksymali-

${ }^{45}$ Uchwała TK z 12 marca 1997 r., W 8/96, w sprawie ustalenia powszechnie obowiązującej wykładni art. 2 pkt 7 i art. 4 ust. 1 pkt 4 ustawy z 10 czerwca 1994 r. o zamówieniach publicznych, OTK 1997, nr 1, poz. 15.

46 Tak M. Stec, M. Mączyński, op. cit., s. 137. 
zację zysku"47. To oznacza, że spektrum możliwych do wykorzystania instrumentów prawnych będących w dyspozycji jst, a wskazanych w GospKomU, jest dość szerokie, obejmuje bowiem zarówno jednostki nieposiadające osobowości prawnej (zakład budżetowy), jak i ją mające, czyli przede wszystkim spółki prawa handlowego będące spółkami kapitałowymi - spółką akcyjną i spółką z ograniczoną odpowiedzialnością ${ }^{48}$.

W konkluzji należy zatem stwierdzić, że zabiegi interpretacyjne i wykorzystanie różnych metod wykładni aktualnie obowiązujących przepisów moga doprowadzić jedynie do częściowego, wysoce niestabilnego, w dużym stopniu bowiem zależnego od stanowiska sądów, rezultatu w postaci adekwatnego do dzisiejszych oczekiwań zarówno samorządu jako organizacji wspólnoty terytorialnej, jak i poszczególnych jej członków, określenia zakresu zadań w sferze aktywności gospodarczej samorządu, mieszczących się w pojęciu użyteczności publicznej, i instrumentów prawnych, którymi może się on posługiwać. Dlatego rozwiązaniem niezbędnym jest przygotowanie nowej ustawy (czy na pewno pod tym samym tytułem?), obecna bowiem jest aktem prawnym całkowicie anachronicznym, uzupełniającym inne ustawy i regulującym tylko wyrywkowo pewne zagadnienia ${ }^{49}$, co prowadzi do tworzenia jedynie kolejnych problemów interpretacyjnych. Ta nowa ustawa winna stanowić akt prawny kreujacy na miarę współczesnych oczekiwań i wyzwań system gospodarki komunalnej jako część gospodarki narodowej, jako sferę, w której jst prowadzą taka działalność gospodarcza, która służy realizacji zadań własnych samorządu terytorialnego, a zatem posiada przymiot użyteczności publicznej. Równocześnie niezbędne byłoby odpowiednie znowelizowanie wszystkich ustaw ustrojowych, którego istota polegałaby na: po pierwsze - uchyleniu tych przepisów, których anachroniczność jest dziśs uderzająca, jak m.in. art. 9 ust. 4 SamGminU czy art. 13 ust. 2 SamWojU, i - po drugie - odesłaniu w całym zakresie problematyki prowadzenia działalności gospodarczej, w tym komunalnej, do tej szczególnej ustawy.

prof. dr hab. Mirostaw Stec

Uniwersytet Jagielloński

ON THE NEED FOR RE-INTERPRETATION (AND NOT ONLY)

OF SOME CONCEPTS OF TERRITORIAL SELF-GOVERNMENT TASKS

AND COMPETENCIES

Sum mary

Among the many issues of territorial self-government law whose interpretation leads to much controversy, one of the main ones is the scope, size and instruments used in business performance of a territorial self-governing unit operating as a business entity. What raises particular doubts is the concept of 'municipal economy' and inseparably bound to it concept of 'public utility'.

${ }^{47}$ Zob. S. Dudzik, op. cit., s. 271 i n.

48 Szerzej na temat zakresu wykorzystywania tych spółek zob. M. Stec, M. Mączyński, op. cit., s. 139 i n.

${ }^{49} \mathrm{Na}$ co trafnie zwracają uwagę C. Banasiński, K. Jaroszyński, Ustawa..., s. 21 i n. 
Both have so far been interpreted based on the grammatical and semantic rules. This interpretation has turned out obsolete as it fails to meet the needs of today, and more specifically, the tasks of the contemporary territorial self-government. It even renders performance of certain functions of a self-governing unit impossible, particularly that of a creator of municipal or regional policy and that of its main executor in the capacity of the development manager. Hence the need to use other methods of interpretation, particularly the functional one and the systemic one. However, to eliminate the doubts arising from the interpretation of the two concepts completely, it will be necessary to adopt new normative solutions in the form of relevant amendments to the law on the political system or a new law on municipal economy. 
